\title{
Italian Students’ Social Representation on Aging: An Exploratory Study of a Representational System
}

\author{
Representações Sociais de Estudantes Italianos sobre o Envelhecimento: Um \\ Estudo Exploratório de um Sistema Representacional
}

\author{
João Wachelke* \& Alberta Contarello \\ Università degli Studi di Padova, Padua, Italy
}

\begin{abstract}
In various countries there are studies aimed at characterizing social representations on aging, but little is known about their relations with other representations. The present study proposes to characterize those relations through the notion of representational systems. An exploratory survey has been conducted with 151 Italian undergraduate students. They have completed evocation tasks about seven social objects linked to aging and also rated the distances among them. Distance ratings went through similarity analysis, while a prototypical analysis was carried out for aging and three objects: death, health and family. The results indicate possible content connections among representation elements and suggest a conjunction relationship between aging and family. The notion of representational systems opens possibilities for more refined representational characterizations.

Keywords: Aging; Social Representations; Structural Approach; Representational Systems.
\end{abstract}

\begin{abstract}
Resumo
Há pesquisas em diversos países sobre representações sociais sobre envelhecimento, mas pouco se sabe sobre suas relações com outras representações. O presente estudo visa caracterizar essas relações através da noção de sistema representacional. Um levantamento de dados exploratório foi conduzido com 151 universitários italianos que completaram tarefas de evocações sobre sete objetos sociais ligados ao envelhecimento e avaliaram as distâncias entre eles. As avaliações de distância passaram por análise de similitude, enquanto que análises prototípicas foram realizadas para envelhecimento e três objetos: morte, saúde e família. Os resultados indicam possíveis conexões de conteúdos entre elementos das representações e sugerem uma relação de conjunção entre envelhecimento e família. A noção de sistemas representacionais abre possibilidades para o refinamento de caracterizações representacionais.

Palavras-chave: Envelhecimento; Representações Sociais; Abordagem Estrutural; Sistemas Representacionais.
\end{abstract}

An essential topic in human development science, aging is a multidimensional process that happens after the sexual maturation of a living organism and exerts influence on its functions, reducing its probability of survival with the passing of time (De Beni, Borella, \& Mammarella, 2009). The theme has growing importance also because of a macro social change: the world population aging phenomenon. In 2007, $10.7 \%$ of the world population was 60 years old or more, which is estimated to rise to $22 \%$ in 2050 (United Nations, 2007).

Beliefs and lay thinking are important variables associated with aging processes. Levy (2003) conducted a thorough review supporting the idea that the stereotypes on the elderly are learned and internalized by people on

*Address: Università degli Studi di Padova, Dipartimento di Psicologia Applicata,Via Venezia 8, Padua, Italy, 35131. E-mails: wachelke@yahoo.com and alberta.contarello@unipd.it their childhood and adolescence, operating as resources to differentiate from the outgroup - in this case, the elders. However, later on, the outgroup becomes the ingroup as people get older, and therefore the stereotypes end up becoming self-stereotypes. Data from cross-cultural and experimental studies indicate that being primed to content from the negative stereotypes about the elderly has situational effects on the elders such as decreasing memory performance and increasing cardiovascular rate. In longitudinal studies, having a positive self-perception on the aging process is linked to a longer life and higher motivation to live. Levy's paper provides substantial evidence that the existence of social beliefs is able to significantly influence personal cognitive and physical processes. In the same vein, Couto, Koller, Novo and Soares (2009) have observed that some of the events that elderly people perceive as generating higher stress levels are the ones that involve social contexts - such as suffering physical and moral violence and being disrespected due to age. 
Gergen and Gergen (2000) point out that the socially shared views on aging are predominantly negative and conceive it as a process that leads to a general decline of the human organism. Yet, at the same time, the authors sustain that the beliefs, conceptions and stereotypes on aging and old age are social constructions that can be changed to more adequate and positive ones, and that if the positive dimensions of the process are emphasized, it is possible to bring about a radical change in the way that old age is understood by people.

The common knowledge about aging has important effects in the lives of elderly people and can affect the organization of social aspects of everyday life related to that issue. If that knowledge is generated socially, socialized to younger people and carried by them throughout life, it is important to characterize their social representations on aging.

\section{Social Representations on Aging}

In the present paper, a structural approach on social representations is adopted (Flament \& Rouquette, 2003). According to it, a social representation is a symbolic knowledge structure shared by the members of a group. A representation contains content that describes, evaluates or explains a social object - a topic, thing or event that is relevant for the everyday lives of group members. The structure of a social representation is formed by elements - basic cognitive units that convey semantic or evaluative properties to the social object - and relations between those elements and the object (Abric, 1994; Lheureux, Rateau, \& Guimelli, 2008). Since both social objects and social representation elements are labeled by verbal signs, in the present text social object labels will be written between square brackets $-[$ ] - while angle brackets $-<>-$ will be employed to refer to social representation elements.

A social representation structure is formed by elements from two integrated and distinguished systems. The central core is formed by the most consensual elements that define the representation object or determine norms to evaluate it and organize the representation. Those elements are more stable and define the identity of the social representation; a change in the central core means a transformation in the structure. In contrast, the peripheral system includes the elements that are less shared and have a conditional nature. They adapt the social representation to particular contexts and guide practices (Abric, 1994; Flament, 1994a).

[Aging] is a topic that qualifies as a social object: it is a thoroughly discussed broad theme that becomes pertinent in many particular contexts, such as the relationship with death and time and the differences between young and old age. There also seems to be a variation in the configuration of representations shared by young and elderly people, which is evidence that age groups, being differently implied by aging, function as social categories associated with specific representations (Gastaldi \& Contarello, 2006; Wachelke, 2008).
There have been plenty of studies conducted with the aim of characterizing the social representations on [aging], as well as others that are practically interchangeable, such as the representations on the [elderly person] and [old age]. The most recurrent result with healthy participants from urban settings is a broad identification of two poles organizing the content of the representations into gains, usually psychological, that constitute the positive aspects of going old; and losses, in general related to a strong decline process, a trend identified first by Veloz, Nascimento-Schulze and Camargo (1999).

There is differentiation in social representation content in terms of age groups. Elders mention more positive and concrete elements in their social representations than younger people (Gastaldi \& Contarello, 2006; Magnabosco-Martins, Camargo, \& Biasus, 2009), and young people, emphasize the positive element of $<$ wisdom $>$ but have a majority of negatively-connoted elements in their representations, such as $<$ decline $>$, <illness $>$ and $<$ death $>$ (Gastaldi \& Contarello, 2006; Gaymard, 2006; Moliner \& Vidal, 2003;Wachelke, 2009; Wachelke et al., 2008).

A few studies were conducted in France and Brazil with the goal of characterizing the structure of the social representations of young adults on aging. A French study with an undergraduate sample identified the following elements of the social representation on the [elderly person] as being central: <experience $>$, $<$ illness $>$, $<$ bad driving skills $>,<$ free time $>$ and $<$ traditions $>$ (Moliner $\&$ Vidal, 2003). Also in France, Gaymard (2006) characterized the structure of the social representation of Nursing students about the same object. The core was formed by elements < dependency $>$, <wisdom>, <experience $>$ and $<$ old age $>$. A study with Brazilian undergraduates participants pointed out to the centrality of the $<$ wisdom $>$ element, as well as $<$ health $>$, $<$ family $>$ and $<$ physical signs $>$ (Wachelke, 2009).

However, if there seems to be considerable advance in terms of the understanding of the structure of the representation on [aging], little is known about the relations that its elements might maintain with other social representations. The present paper intends to contribute to the identification of inter-representation relations that might shed light to the characterization of the representation on [aging]. This is possible through a notion introduced at a theoretical level of the social representations literature: the representational system.

\section{Representational Systems}

Moscovici (1961/1976) proposed that social representation contents were anchored in pre-existing knowledge, which provided the interpretation resources to construct new representations. Breakwell (1993) pointed out that a clear derivation of the anchoring process is that social representations are organized in networks: each representation is inevitably connected with others, and therefore representation relationships must be taken into account. 

System.

Garnier (1999) stated that different representations that maintain structural relationships with each other at the level of their structures form a system. She conducted research about the representations of children on three objects: [body], [health] and [environment]. Those representations were contextualized in a system about human relations.

Milland (2001) obtained results with the representations of students and young unemployed workers on [work] and [unemployment] that supported a view implying that the representation on [unemployment] is structured having the representation on [work] as a normative reference point, in the case of students who do not have practical experience with both objects. The author demonstrated that a transformation in one representation might bring about a transformation in another representation of the same system.

More recently, Pianelli, Abric and Saad (2010) conducted research demonstrating that the social representations of drivers on [speed] and [speed limitation] form a network with the emerging representation on a technological device developed in France to control car speed, named LAVIA. The associations found in their results suggest that the representation related to [LAVIA] technology is generated anchored to representations of subgroups of drivers with different profiles regarding driving behavior and the other representations of the system.

But how are the representations included in a system linked to each other? The classification proposed by Flament and Rouquette (2003) about relations among social representations is useful to envisage the configurations of coordination among representations. According to central core similarity, coordination relations can be classified in two subtypes: disjunction and conjunction. Disjoint representations have no intersection whatsoever in the cores of related representations, in terms of a coincidence of verbal signs referring to elements. On the other hand, conjunction involves representations with intersecting central cores. A second possibility, not directly addressed by the authors, is the case in which the object label that refers to one of the representations is central or peripheral in the structure of another representation.

\section{Research Aims}

Based on the reviewed literature, it is hypothesized that [aging] maintains structural relationships with broad notions that could as well be relevant social objects for samples of young or elderly people. If that is the case, then it does make sense to conceive [aging] within a representational system, a set of representations that are interconnected and mutually dependent on each other, forming a higher-order structure.

In order to have a first exploration of the representational system constructed around the social representation on [aging], a survey has been conducted with the aim of characterizing the shared knowledge about seven social objects that might constitute the representational system: [aging] itself, [health], [family], [body], [work], [time] and [death].

It is important to justify their condition as social objects. We will be brief, though, and point out that most of them have already been productively studied as social representation objects, as evidenced by the existence of empirical studies in the literature. The social representation on [work] has been the topic of various studies aligned with a structural perspective (Milland, 2001; Oliveira, Fischer, Amaral, Teixeira, \& Sá, 2005). The remaining social representations, i.e. [health] (Herzlich, 1969), [body] (Goetz, Camargo, Bertoldo, \& Justo, 2008), [time] (Ramos, 1992) and [family] (Costa e Silva \& Cunha, 2005) have been the focus of other social representations approaches.

The meanings of elements from the social representation on [aging] that have been identified in research - aligned with a structural approach or not - provide hints of possible links with the other representations. The social representation on [health] might be related to healthrelated elements of [aging], such as $<$ illness $>$ or $<$ general decline $>$. [Body] is also related to <general decline $>$, as the decrease of capacities and constitution is strongly physical. Since $<$ family life $>$ is potentially an important element of [aging], it is closely connected with the understanding that people have of families, and therefore the social representation on [family] is key. The passing from a working situation to retirement evidences the importance of taking into account the social representation on [work] in the system. [Time] is the main dimension that organizes the understanding and diagnosis of the aging process. [Death] is the event in which life ends, and since old age is the phase that usually precedes it, probably both representations are intimately connected.

The study was conducted with a population of young Italian undergraduates. We have chosen to have young participants as it is a population that is not directly affected by aging and already gets in contact with the shared knowledge about it. Moreover, that knowledge might later backfire, if we take the research reviewed by Levy (2003) into account, which indicates that stereotypes are internalized and kept to a large extent throughout their lives.

Italy is a unique setting to carry out research about the social representations on aging, since it holds one of the top positions among the countries with the oldest populations, after a change in population structure that happened at a fast pace. Currently 26\% (over 15 million Italians) of its population is 60 years old or older, and $20 \%$ (about 12 million) is 65 years or older, which makes of Italy the $2^{\text {nd }}$ country with the highest proportion of elderly people in the world (Istituto Nazionale di Statistica [Istat], 2009; United Nations, 2007).

\section{Method}

\section{Design}

The study was an exploratory survey that aimed at characterizing the representational system containing the 
social representation on aging at two levels: within and inter-representation. At the inter-representational level, it aimed at assessing the perceived similarities among objects, in order to select a few of those social representations for further analyses. A second aim involved the characterization of the selected social representations at the within-representation (structural status and affective loadings of elements), to infer possible relations between those representations and the representation on [aging].

\section{Participants}

A total of 151 Psychology undergraduates from the University of Padua (Italy) composed a convenience sample for the study; 110 (72.8\%) were women. Their age ranged from 19 to 28 years old, with a mean of 21.43 years $(S D=1.85)$ and a median of 21 years.

\section{Instrument}

A questionnaire in Italian language composed mainly by evocation tasks was employed. On the opening page, participants were informed that they would provide their opinions about themes of social life, with no specific mention of aging. After that, they had to fill seven pages containing detailed evocation tasks, each with a stimulus word which supposedly labels one social representation related to [aging]: [aging] itself, [time], [death], [health], [body], [work] and [family].There were 12 versions of the questionnaire, each with different presentation orders, randomly generated, so as to minimize any effect due to exposure to a label prior to answering questions regarding another one.

For each stimulus word, participants were asked to write down three words or expressions that came to their minds when thinking about the representation label. Each response was identified by a code (for example, Response $\mathrm{B} 1$ or $\mathrm{B} 2$ ), and below the association task there was one item destined to assess the affective load of the response. The participant should indicate whether the response was negative, neutral, or positive.

Finally, participants estimated the distances between the stimulus words presented before on a four-point scale from "far" to "close. The stimuli were evaluated in pairs.

\section{Procedure}

Questionnaires were administered in university classrooms by the researcher. The versions were shuffled, so as to assign them randomly to participants.

\section{Data Analysis}

The analysis dealt with two structural levels of social representations: the structural relationships among representations (which we called inter-representation level) and the structure of each representation in terms of elements (within-representation level). Here, the interrepresentational level comprises the assessment of connections between two or more social representations, making it possible to sketch the organization of the representational system, as the units of interest are social representation object labels. The within-representation level refers to the characterization of content and structural status of elements from each social representation separately.

For the inter-representation level, a similarity matrix was constructed from the rated distances of social object labels contained on the last page of the instrument. Each response linking two objects was recoded from 0 to 3 and the mean profiles for each item were calculated and divided by three, providing a result from 0 to 1 . A similarity maximum tree, a graph with vertexes and edges connecting all objects with a single path between any two vertexes on the graph (Degenne \& Vergès, 1973) was then drawn from the departure matrix.

Then prototypical analysis (Vergès, 1992) was conducted for some objects, at the within-representation level. The analysis consists on the calculation of word ranks and frequencies and a segmentation of both dimensions based on high or low values. The same construction principles were respected for all prototypical analysis tables. Only words with frequencies 5 or higher were included on the tables. The median rank, 2, was employed as a cut-off point between low-rank words (those mentioned earlier in discourse, with rank lower than 2) and high-rank ones (with average rank 2 or higher). As for the frequency cut-off point, it was equivalent to the frequency immediately above $30 \%$ of word occurrences.

The quadrants from prototypical analysis were organized according to the frequency and mean evocation rank criteria, but three supplementary indexes were presented in the tables. The first one was the proportion of rank 1 responses for each word, having in mind that the relationship with average word rank and element centrality in social representations might not be always accurate (Wachelke, 2008). The cut-off point to decide whether a word has a high or low proportion on this index was determined through a median split of the proportions of words with frequencies higher than 5 . The grouping of similar words for prototypical analysis was only done for words with the same root and grammar class, so as to avoid possible biases from content procedures (cf. Flament \& Rouquette, 2003).

For the evaluation of the affective loadings of each element, an adaptation of the polarity and neutrality indexes proposed by De Rosa (1995) was employed. Instead of calculating those indexes for a whole representation, indexes were calculated for each word type. The polarity index was calculated through summing positive and negative occurrences of a type and dividing the total by total occurrences of that type. The result could range from -1 (completely negative) to +1 (completely positive), with results close to 0 indicating neutral polarity, 
either by means of the prevalence of neutral responses or by a balance of positive and negative words. The neutrality index is obtained by subtracting the sum of positive and negative occurrences from the total of neutral occurrences, and dividing the result by the total number of type occurrences. It can range from -1 (no neutral words) to +1 (all words are neutral). A 0 result indicates that an equal number of affectively loaded and neutral words.

The similarity analysis was carried out through the software Similitude (Junique, Barbry, Scano, Zeliger, \& Vergès, 2002). The other analyses were processed on Evocation (Scano, Junique, \& Vergès, 2002), Microsoft Excel and SPSS software.

\section{Results}

\section{Inter-representational Level}

Concerning the data involving direct paired distances, the similarity structure for the rated distances among social objects has [aging] as the most connected vertex on the graph, directly linked to three other social objects: [time], [death] and [body], as shown in Figure 1. This is coherent with the fact that the representation system comprising the eight social objects was conceived with [aging] as a reference point, and thus provides some evidence of the pertinence of chosen social objects for the effort. The pattern of data clearly shows that, according to participants, it is a central vertex in terms of connectivity.

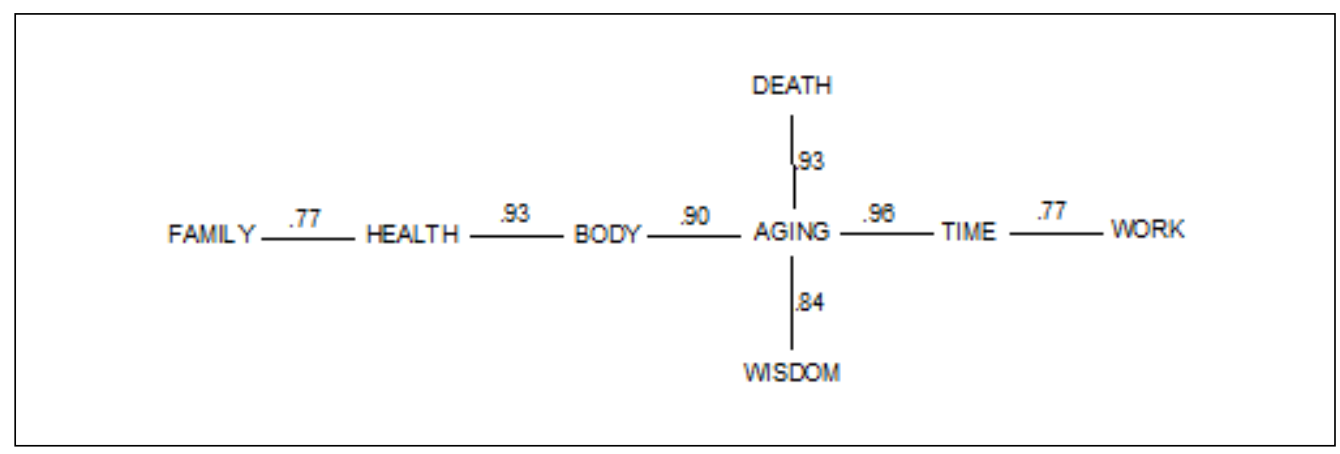

Figure 1. Maximum similarity tree from direct rated distances among the social objects.

Upon considering the results of similarity analysis, we decided to proceed with the prototypical analysis of three objects. We chose to work with [death], [health] and [family]. [Death] was chosen due to its high proximity with [aging]. We chose [health] rather than [body] due to the fact that it is a more abstract and general class and probably includes many of the relevant aspects of [body], as the edge that connects them is high. Moreover, [health] is probably more directly related than [body] to some of the aspects of [aging] that are of our interest: <general decline $>$ and $<$ health problems $>$. Contrastingly, [family] gives an interesting comparison reference, as it is an object perceived as being less linked to [aging] than most of the others. Still, the $<$ family $>$ element in [aging] is often central, and the representation on [family] is probably the most closely linked to it.

We have carried out the prototypical analysis also for [time], the object perceived by participants as being closest to [aging]. However, the observation of responses indicated a mere descriptive tendency regarding time, with little interest in a social dimension. The most mentioned words relate to attributed qualities of time, such as it being $<$ free $>$ and $<$ fast $>$. There are also associations related to time in the sense of weather, which is legit in Italian language. We chose not to proceed with the analysis of that object as it seems that the structure of the representation, in that case, was not well captured by the employed technique.

\section{Prototypical Analysis}

The results for the prototypical analyses relative to the five retained objects are presented in Table 1 . It includes the cut-off points for frequencies $(F)$, the median rank 1 proportion (M1), the proportion of word occurrences in high frequency quadrants, the frequency counts for each word type (with rank 1 proportions in parentheses), and the associated polarity and neutrality indexes.

The results for [aging] show that $<$ wisdom $>$ is the most mentioned word, indicated by almost one fifth of the sample. $<$ Grandparents $>$, a word related to a more general $<$ family $>$ element, is very close in frequency, and its average rank is smaller. Also, the proportion of times mentioned in rank 1 is higher in comparison to $<$ wisdom $>$. Other words in the first quadrant include the $<$ elderly person $>$ and $<$ loneliness $>-$ interpreted here as one of the particular examples of $<$ social exclusion $>-$ and < wrinkles>. 
Table 1

Prototypical Analyses for the Four Retained Social Objects

\begin{tabular}{|c|c|c|c|c|c|c|c|c|c|c|c|}
\hline \multirow[b]{2}{*}{ Object } & \multicolumn{5}{|c|}{ Rank $<2$} & \multicolumn{6}{|c|}{ Rank $>2$} \\
\hline & & Type & Freq. & Rank (pr. 1) & Pol. & Neut. & Type & Freq. & Rank (pr. 1) & Pol. & Neut. \\
\hline \multirow{11}{*}{ 岂 } & $F>17$ & wisdom & 28 & $1.82(.42)$ & 1.00 & -1.00 & death & 34 & $2.12(.24)$ & -.85 & -.82 \\
\hline & (34.9\%) & grandparents & 26 & $1.69(.53)$ & .58 & -.15 & illness & 17 & $2.11(.24)$ & -1.00 & -1.00 \\
\hline & & elderly & 18 & $1.67(.50)$ & -.06 & .67 & & & & & \\
\hline & & loneliness & 18 & $1.94(.44)$ & -.83 & -.67 & & & & & \\
\hline & & wrinkles & 17 & $1.53(.58)$ & -.65 & -.29 & & & & & \\
\hline & $F<17$ & age & 10 & $1.50(.60)$ & .00 & .60 & sadness & 11 & $2.27(.18)$ & -.91 & -.82 \\
\hline & & time & 10 & $1.70(.60)$ & -.10 & .80 & old age & 5 & $2.00(.20)$ & -.60 & -.20 \\
\hline & $\mathrm{M} 1=40$ & loss & 8 & $1.75(.38)$ & -1.00 & -1.00 & change & 5 & $2.40(.20)$ & .00 & 1.00 \\
\hline & & experience & 8 & $1.88(.25)$ & 1.00 & -1.00 & white hair & 5 & $2.60(.20)$ & -.40 & .20 \\
\hline & & decay & 7 & $1.71(.43)$ & -1.00 & -1.00 & end & 5 & $2.60(.00)$ & -1.00 & -1.00 \\
\hline & & maturity & 5 & $1.20(.80)$ & .80 & -.60 & & & & & \\
\hline \multirow{14}{*}{ 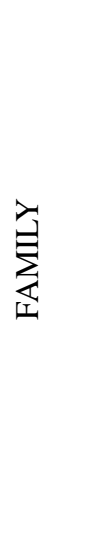 } & $F>20$ & home & 34 & $1.88(.41)$ & .56 & -.12 & love & 31 & $2.07(.35)$ & 1.00 & -1.00 \\
\hline & (33.6\%) & union & 25 & $1.64(.52)$ & 1.00 & -1.00 & children & 21 & $2.23(.19)$ & .67 & -.52 \\
\hline & & affect & 21 & $1.91(.24)$ & 1.00 & -1.00 & & & & & \\
\hline & & parents & 20 & $1.45(.60)$ & .65 & -.50 & & & & & \\
\hline & $F<20$ & mommy & 16 & $1.50(.63)$ & .94 & -.88 & support & 11 & $2.00(.36)$ & .91 & -.82 \\
\hline & & unity & 11 & $1.64(.55)$ & 1.00 & -1.00 & security & 8 & $2.13(.38)$ & 1.00 & -1.00 \\
\hline & $\mathrm{M} 1=40$ & father & 10 & $1.60(.40)$ & .60 & -.20 & protection & 6 & $2.17(.33)$ & 1.00 & -1.00 \\
\hline & & mother & 9 & $1.67(.44)$ & .56 & -.11 & sister & 6 & $2.83(.00)$ & .67 & -.33 \\
\hline & & sharing & 9 & $1.89(.22)$ & .89 & -.78 & help & 5 & $2.00(.20)$ & .60 & -.20 \\
\hline & & warmth & 7 & $1.57(.57)$ & 1.00 & -1.00 & group & 5 & $2.00(.40)$ & .60 & -.20 \\
\hline & & kids & 6 & $1.50(.50)$ & 1.00 & -1.00 & link & 5 & $2.20(.40)$ & 1.00 & -1.00 \\
\hline & & core & 6 & $1.50(.67)$ & .67 & -.33 & relatives & 5 & $2.20(.20)$ & .80 & -.60 \\
\hline & & numerous & 6 & 1.50 (.67) & .83 & -.67 & marriage & 5 & $2.40(.00)$ & 1.00 & -1.00 \\
\hline & & & & & & & serenity & 5 & $2.40(.20)$ & 1.00 & -1 \\
\hline \multirow{14}{*}{ 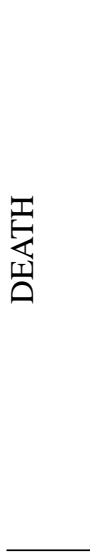 } & $F>12$ & end & 38 & $1.82(.50)$ & -.58 & -.37 & & & & & \\
\hline & (30.2\%) & pain & 32 & $1.78(.41)$ & -.94 & -.88 & & & & & \\
\hline & & sadness & 29 & $1.69(.48)$ & -.90 & .79 & & & & & \\
\hline & & fear & 26 & $1.81(.46)$ & -.96 & -.92 & & & & & \\
\hline & & illness & 12 & $1.67(.50)$ & -.92 & -.83 & & & & & \\
\hline & $F<12$ & tomb & 11 & $1.64(.45)$ & -.27 & .45 & suffering & 11 & $2.27(.00)$ & -1.00 & -1.00 \\
\hline & & grief & 10 & $1.70(.50)$ & -.70 & -.80 & loneliness & 9 & $2.33(.22)$ & -.89 & -.78 \\
\hline & $\mathrm{M} 1=41$ & cemetery & 10 & $1.80(.40)$ & -.20 & .60 & life & 8 & $2.00(.50)$ & .38 & .25 \\
\hline & & old age & 10 & $1.90(.40)$ & .40 & -.20 & crying & 7 & $2.00(.26)$ & -.86 & -.71 \\
\hline & & loss & 9 & $1.89(.56)$ & -1.00 & -1.00 & inevitable & 6 & $2.00(.33)$ & -.50 & -.67 \\
\hline & & funeral & 8 & $1.50(.50)$ & -.38 & -.25 & unknown & 5 & $2.40(.00)$ & -.20 & -.20 \\
\hline & & dark & 8 & $1.88(.50)$ & -.63 & -.25 & empty & 5 & $2.40(.20)$ & -1.00 & -1.00 \\
\hline & & black & 6 & 1.67 (.33) & -.33 & .33 & & & & & \\
\hline & & sad & 5 & $1.60(.40)$ & -.80 & -.80 & & & & & \\
\hline \multirow{14}{*}{ 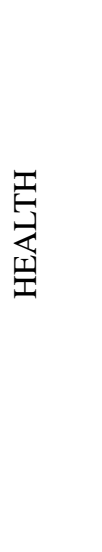 } & $F>15$ & well-being & 49 & $1.63(.55)$ & 1.00 & -1.00 & hospital & 25 & $2.08(.32)$ & -.08 & .20 \\
\hline & (30.0\%) & illness & 28 & $1.64(.50)$ & -.89 & -.93 & & & & & \\
\hline & & life & 19 & $1.84(.50)$ & .89 & -.79 & & & & & \\
\hline & & good & 15 & 1.47 (.73) & .93 & -0.87 & & & & & \\
\hline & $F<15$ & happiness & 10 & $1.90(.30)$ & 1.00 & -1.00 & doctor & 12 & $2.00(.42)$ & & \\
\hline & & physique & 9 & $1.89(.44)$ & .56 & -.11 & care & 10 & $2.40(.00)$ & .00 & -.20 \\
\hline & $\mathrm{M} 1=33$ & luck & 5 & $1.80(.60)$ & .60 & -.20 & sport & 9 & $2.00(.22)$ & .67 & -.33 \\
\hline & & important & 10 & $1.70(.30)$ & .70 & -.40 & youth & 8 & $2.25(.25)$ & .25 & .50 \\
\hline & & medicine & 12 & $1.83(.33)$ & .33 & -.33 & mental & 8 & $2.63(.00)$ & .13 & .25 \\
\hline & & & & & & & to be well & 6 & $2.00(.33)$ & 1.00 & -1.00 \\
\hline & & & & & & & body & 6 & $2.17(.33)$ & .33 & .33 \\
\hline & & & & & & & physic. activ. & 5 & $2.20(.20)$ & 1.00 & -1.00 \\
\hline & & & & & & & health(sanità) & 5 & $2.20(.40)$ & .40 & -.60 \\
\hline & & & & & & & serenity & 5 & $2.40(.20)$ & .80 & -.60 \\
\hline
\end{tabular}


In the quadrant with high frequencies but also high ranks, <death > is the most remarkable element, as it is the most cited word overall. Its average rank (2.21) is not too far from the median cut-off point of 2 , but the proportion of times in rank 1 is below the median value of 40 , certifying the exclusion of that word from the first quadrant according to prototypical criteria. The frequency of <illness $>$ is lower and barely above the cut-off point. The contrasting quadrant (low frequencies and ranks) has words that are semantically related, such as $<$ loss $>$ and $<$ decay $>-$ both related to the $<$ general decline $>$ element - , or the $<$ time $>$ and $<$ age $>$ pair. $<$ Maturity $>$ and $<$ experience $>$ also bear meaning similarities to $<$ wisdom $>$.

Both low-frequency quadrants contain words that refer to particularities of more global dimensions that are related to some of the most cited words. The observation of polarity and neutrality indexes confirms that [aging] has both strongly positive and negative elements, as suggested by the literature that identifies an opposition of gains and losses.

Three elements are clearly salient on prototypical analysis results relative to [family]: $<$ home $>,<$ union $>$ and $<$ parents $>$. $<$ Home $>$ is the most mentioned word, but $<$ parents $>$ refers to a general class which includes other words such as $<$ mommy $>$, <mother $>$ and $<$ father $>$, which are also on the superior cut-off point half concerning average rank and rank 1 responses. $<$ Union $>$, a word that refers to cohesion, introduces a general element class that could include <unity>, which is contained in the contrasting elements quadrant. <Affect> is in the first quadrant, but its rank 1 proportion is below the median cut-off point. However, taken together with words from other quadrants such as love and warmth it forms a set linked to <love $>$. $<$ Love $>$ itself is fairly cited but it is below the cut-off point on the rank criteria.

The first peripheral quadrants - high frequency and rank, and the contrasting elements zone - present two interchangeable notions, <children $>$ and $<$ kids $>$. Also, the most cited word on the far peripheral quadrant, <support>, provides the traces for a logic that could guide the grouping of other words which are related in meaning, such as < security $>$, <protection $>$ and $<$ help $>$. The representation field concerning family seems to be organized by the elements $<$ home $>$, $<$ union $>$ and $<$ parents $>$, while other elements emerging from the grouping of words - possibly labeled as <love>, <children> and $<$ support $>$ also play an important role on the representation. Additionally, all the words have positive loadings.

There was no quadrant in the analysis of [death] with elements with both high frequencies and ranks, which indicates a more clear-cut organization of the important elements. Such a statement is also supported by their high rank 1 proportions. The most mentioned word is <end $>$ : death is perceived as the end of a period or cycle. The other four elements from the first quadrant provide the basis for the main elements of the representation. $<$ Pain $>$ can be related to <suffering $>$, a word from the fourth quadrant. $<$ Sadness $>$ is linked to $<$ crying $>$, also on the fourth quadrant, and $<$ grief $>$ and $<$ sad $>$ on the contrasting elements zone. $<$ Fear $>$ regards the emotional reaction towards death, justifiable once that the other elements are taking into consideration. <Illness $>$ is on the first quadrant but its frequency is precisely on the cut-off for the frequency criterion. This indicates a less stable position of illness on the representation field, as it might result from a casual configuration of data. Finally, some words from the contrasting zone relate to concrete situations and objects in which death is experienced, such as the $<$ tomb $>$ and $<$ funeral $>$. Others are more abstract symbols such as $<$ black $>$ and $<$ dark $>$. Most elements have a negative connotation.

The prototypical analysis on [health] had the lowest rank 1 proportion of all stimulus words analyses, indicating a certain pulverization of the representation. The emphasized word in the first quadrant is <wellbeing>, with a superior classification in all criteria. Possibly, words from other quadrants which are related to this concept are $<$ happiness $>$ and $<$ to be well $>$. The word $<$ illness $>$, from the first quadrant, indicates a relationship of opposition with [health]. The words $<$ life $>$ and $<$ good $>$ are also in the first quadrant, but with lower frequencies, and their meanings do not say much in terms of social dimensions.

The quadrant with high frequencies and ranks contains only the word $<$ hospital $>$. The presence of the words $<$ medicine $>$ and $<$ doctor $>$ in the remaining quadrants suggests that they could be classified in a more general element labeled $<$ medical care $>$. The $<$ physique $>$ word, as well as $<$ body $>$, $<$ physical activity $>$ and $<$ sport $>$, could also be integrated in a more global element. Most elements are positive or neutral, with the exception of $<$ illness $>$.

\section{Discussion}

The results of the similarity analysis confirm that the choice of objects for the study was pertinent, as the direct evaluations of participants point out that [aging] is the key representation to organize the whole set: it is as if the other ones fit the system to the extent that they are associated with [aging], even if some might be more connected to other objects.

The results from the prototypical analyses of the four social objects that were retained for in-depth investigation of their structures allowed to identify some well structured social representation for our sample of young Italian students. [Aging] is represented as a process that is connected to death, and one's grandparents are already on the final part of it, as well as elderly people in general. It is marked by generalized decline in many aspects of life. The various positive and negative elements in the analysis quadrants are an evidence that overall it is a 
representation marked by a coexistence of gains and losses, a general pattern found in other studies (Veloz et al., 1999; Wachelke et al., 2008).

[Death] is represented as an event leading to the end of one's existence, and thinking of it or reacting to other people's deaths is associated with emotional reactions such as sadness, suffering and fear, which is compatible with results from other studies. Yet, the absence of elements of a religious nature such as <passing > and $<$ return> contrasts our results to research conducted with Brazilian health professionals (Nascimento \& Roazzi, 2007).

For our sample, a [family] is a social unit in which parents are there, and its members love each other and are very united. It is a context in which people usually find support. Finally, it is a unit associated with the raising and the presence of children. It does seem that participants usually refer to a nuclear family - mother, father and children - when they have to think about a family unit. It is interesting to note that grandparents and elderly people are not part of that scenario; rather, they would be there in the case of extended families.

The shared knowledge about [health] is centered on the notions of well-being and the contrast with illness. Other elements refer mostly to contexts and actors related to health care.

If we take the most important elements of each representation - the high frequency quadrants - and interpret their meanings, it is possible to make sense of likely coordination relations between social represen-tations, at the level of connections between social object labels and representation elements, and between elements from different representations. In the first case, we speak of elements that have their meaning related to a whole another social representation structure, and by linking them to a object label we mean that it is necessary to take the meaning of the whole representation complex to try to understand the relation. In the second case, there might be a hint on which elements of the related representations might be linked to the first element. Since our goal is to identify inter-representation relations involving [aging], we will only deal with relations concerning that object.

There are three elements from [aging] with contents that are probably related to the other representations. $<$ Illness $>$ is probably related to [death] and [health]. The understanding that to age is to probably have to face health pro-blems and illness means that one has to understand the relationship maintained by the concept of illness with the concept of [health], and that also involves < well being $>$. Depending on what that concept is, the understanding that aging is affected by illness or the qualification acquired by the <illness $>$ element might change.

The element $<$ grandparents $>$ from [aging] is an evident element linked to a [family] role, to be understood according to the whole meaning complex that is the social representation on [family]. Also, the <death> element from the representation on [aging] is labeled by a verbal sign that also labels the social object [death], indicating that the global representation on [death] qualifies the meaning of the <aging-death> element.

We chose not to refer to the central or peripheral status of prototypical analysis elements since we depart from the understanding that they do not really constitute social representation elements in the strict sense; many of them might be grouped or classified into more general elements that probably do a better job as representation elements. Evocations usually are particular expressions of more general elements, and even Vergès (1992) has arrived to more general elements through categorization and classification.

Also, the fact that word evocation tasks are heavily affected by context salience effects (Guimelli \& Deschamps, 2000) means that they provide less stable and sometimes misleading results. The case of $<$ wisdom $>$ is a good example; although most studies arrive to the conclusion that it is a central element, there is evidence from research employing that points out to it being a peripheral element (Wachelke, 2009; Wachelke \& Lins, 2008), which makes it sensible to consider prototypical analysis results with caution, in terms of structural status.

Our results also point out to the possibility that two social representations from the system maintain a conjunction relation. If we try to group some of the found elements from prototypical analysis into more general and relevant elements, the <grandparents> element from [aging] could be translated easily into a $<$ family life $>$ or $<$ family $>$ element. In that case, if there is really a coordination relation between [aging] and [family], and especially if it is found that there is a peripheral element related to the aging process within the structure of [family], then we would come across a configuration close to that of an embedding relation (Abric \& Vergès, 1996). In that type of relation, the verbal sign assigning the social object label from one social representation is contained in the core of another one, and the social object label from the second representation designates a peripheral element in the structure of the first one. The social representation on [aging] would then be subordinate to the representation on [family]. No peripheral element related to [aging] in the structure of [family] was identified in this study; further research employing different representation characterization techniques might explore that possibility, though. In contrast, we would be reluctant to point out conjunction relations between [aging] and [death] or [aging] and [health] because the intersections of elements and object labels such as < death $>$ or $<$ illness $>$ refer to peripheral elements of [aging], and not central ones.

The study consisted of an exploratory survey on possible relations involving the social representation on [aging] within the representational system that it organizes. All inter-representation element relations were inferred from the contents of those elements. The results allow for the identification of associations of shared knowledge 
structures that might help explain the contents of the social representation on [aging], and as such it adds up to the pertinence of characterizing social representation systems rather than just isolated structures; also, the identification of social representation 'borders' or limits is a long-debated and still unresolved issue (Flament, 1994b; Flament \& Rouquette, 2003), determined by research decisions. If so, it becomes important to take into account the network of relations that different representations maintain; one object being understood according to what people think about a second object or a specific aspect of it, and so on.

Although the integration of complementary information to prototypical analysis - polarity and neutrality indexes and rank 1 proportions - was fruitful, providing more detail to guide the interpretation of data, the instability and context-vulnerability of prototypical analyses as well as the somewhat subjective identification of interrepresentation relations possibly constituted the main limitations of the study. Further research is needed to provide more refinement to those results and arrive to a clear and stable characterization of those relations, through the characterization of the structural status of elements by means of questioning tasks (Moliner, 1994) and the assessment of inter-representation relations through a formal model such as the basic cognitive schemes model (Guimelli \& Rouquette, 1992).

The consideration of the level of representational systems makes it possible to proceed further with the study of social representations, not only concerning [aging] but potentially all social representations that are involved into coordinated networks with others. At different times and sociocultural contexts social representations about the same objects would probably take different relational configurations, as social representations are associated with intergroup relations and communication contexts. In future studies, it will always be necessary to characterize local relationships in terms of structured content associations, which does not rule out the possibility that some patterns are eventually replicated across contexts. However, what is truly in the interest of the theoretical development of a structural approach is the unveiling of global processes related to representational system formation and dynamics which are able to be generalized independently of content and context.

The research has made it possible to present some new relations to guide future research and intervention concerning the shared knowledge about aging. The study has been conducted with young people only and in Italy, which is representative of a reality in which population aging is at a very advanced level; it is important to conduct similar studies in other countries, especially developing and emerging countries that are still young but undergoing an accelerated aging process, in order to identify similarities and differences and the effects of social variables in the beliefs about old age and related proces- ses. A project of that sort would be key in the mapping of how people are adapting to the global change in population structure in their specific contexts, in terms of the networks of concepts that are mobilized by it.

\section{References}

Abric, J.-C. (1994). L’organisation interne des representations sociales: système central et système périphérique. In C. Guimelli (Ed.), Structures et transformations des représentations sociales (pp. 73-84). Lausanne, Switzerland: Delachaux et Niestlé.

Abric, J.-C., \& Vergès, P. (1996). L'étude des relations entre différents objets de représentation: noyau central, emboîtement et réciprocité. Paper presented at the Third International Conference on Social Representations, Aix-enProvence, France.

Breakwell, G. M. (1993). Social representations and social identity. Papers on Social Representations, 2, 1-20.

Costa e Silva, A. L., \& Cunha, C. A. (2005). Representações sociais de família para um grupo de professoras. PSIC - Revista de Psicologia da Vetor Editora, 6(2), 1-9.

Couto, M. C. P. P., Koller, S. H., Novo, R., \& Soares, P. S. (2009). An assessment of the discrimination against older persons in the Brazilian context - Ageism. Psicologia: Teoria e Pesquisa, 25(4), 509-518.

De Beni, R., Borella, E., \& Mammarella, I. (2009). Temi, problemi e prospettive della psicologia dell'invecchiamento. In R. De Beni (Ed.), Psicologia dell'invecchiamento (pp. 1551). Bologna, Italia: il Mulino.

De Rosa, A. S. (1995). Le “réseau d’associations” comme méthode d'étude sur les RS: structure, contenu et polarité du champ semantique. Cahiers Internationaux de Psychologie Sociale, 28, 96-122.

Degenne, A., \& Vergès, P. (1973). Introduction à l'analyse de similitude. Revue Française de Sociologie, 14, 471-512.

Flament, C. (1994a). Aspects périphériques des representations sociales. In C. Guimelli (Ed.), Structures et transformations des représentations sociales (pp. 85-118). Lausanne, Switzerland: Delachaux et Niestlé.

Flament, C. (1994b). Structure, dynamique et transformation des representations sociales. In J. C. Abric (Ed.), Pratiques sociales et representations (pp. 37-58). Paris: Presses Universitaires de France.

Flament, C., \& Rouquette, M.-L. (2003). Anatomie des idées ordinaires. Paris: Armand Colin.

Garnier, C. (1999). La genèse des représentations sociales dans une perspective développementale. In M.-L. Rouquette \& C. Garnier (Eds.), La genèse des représentations sociales (pp. 87-113). Montreal, Canada: Nouvelles.

Gastaldi, A., \& Contarello, A. (2006). Una questione di età: rappresentazioni sociali dell'invecchiamento in giovani e anziani. Ricerche di Psicologia, 20(4), 7-22.

Gaymard, S. (2006). The representation of old people: Comparison between the professionals and students. Revue Internationale de Psychologie Sociale, 19(3-4), 69-91.

Gergen, K. J., \& Gergen, M. M. (2000). The new aging: Self construction and social values. In K. W. Schaie (Ed.), Social structures and aging (pp. 281-306). New York: Springer.

Goetz, E. R., Camargo, B. V., Bertoldo, R. B., \& Justo, A. M. (2008). Representação social do corpo na mídia impressa. Psicologia e Sociedade, 20(2), 226-236. 
Guimelli, C., \& Deschamps, J.-C. (2000). Effets de contexte sur la production d'associations verbales: le cas des représentations sociales des Gitans. Cahiers Internationaux de Psychologie Sociale, 47-48, 44-54.

Guimelli, C., \& Rouquette, M.-L. (1992). Contribution du modèle associatif des schèmes cognitifs de base à l'analyse structurale des représentations sociales. Bulletin de Psychologie, 45(405), 196-202.

Herzlich, C. (1969). Santé et maladie: analyse d'une représentation sociale. Paris: Mouton.

Istituto Nazionale di Statistica. (2009). Annuario statistico italiano 2009. Roma: Autore.

Junique, C., Barbry, W., Scano, S., Zeliger, R., \& Vergès, P. (2002). L'analyse de similitude de questionnaires et de données numériques, SIMI2000 [Manuel software]. Aix-enProvence, France.

Levy, B. R. (2003). Mind matters: Cognitive and physical effects of aging self-stereotypes. Journal of Gerontology: Psychological Sciences, 58B(4), 203-211.

Lheureux, F., Rateau, P., \& Guimelli, C. (2008). Hiérarchie structurale, condionnalité et normativité des représentations sociales. Cahiers Internationaux de Psychologie Sociale, 77, 41-55.

Magnabosco-Martins, C. R., Camargo, B. V., \& Biasus, F. (2009). Representações sociais do idoso e da velhice de diferentes faixas etárias. Universitas Psychologica, 8(3), 831-847.

Milland, L. (2001). De la dynamique des rapports entre représentations sociales du travail et du chômage. Unpublished doctoral dissertation, Université de Provence, Aix-en-Provence, France.

Moliner, P. (1994). Les méthodes de répérage et d’identification du noyau des représentations sociales. In C. Guimelli (Ed.), Structures et transformations des représentations sociales (pp. 199-232). Lausanne, Switzerland: Delachaux et Niestlé.

Moliner, P., \& Vidal, J. (2003). Stéréotype de la catégorie et noyau de la représentation sociale. Revue Internationale de Psychologie Sociale, 16(1), 157-176.

Moscovici, S. (1976). La psychanalyse, son image et son public. Paris: Presses Universitaires de France. (Original work published 1961)

Nascimento, A. M., \& Roazzi, A. (2007). A estrutura da representação social da morte na interface com as religiosidades em equipes multiprofissionais de saúde. Psicologia: Reflexão e Crítica, 20(3), 435-443.

Oliveira, D. C., Fischer, F. M., Amaral, M. A., Teixeira, M. C. T. V., \& Sá, C. P. (2005). A positividade e a negatividade do trabalho nas representações sociais de adolescentes. Psicologia: Reflexão e Crítica, 18(1), 125-133.

Pianelli, C., Abric, J.-C., \& Saad, F. (2010). Rôle des représentations sociales préexistantes dans les processus d'ancrage et de structuration d'une nouvelle représentation. Cahiers Internationaux de Psychologie Sociale, 86, 241-274.

Ramos, J.-M. (1992). De la gestion du temps et de sa représentation sociale. Bulletin de Psychologie, 45(405), 289-300.

Scano, S., Junique, C., \& Vergès, P. (2002). Ensemble de programmes permettant l'analyse des évocations, EVOC2000 [Manuel software]. Aix-en-Provence, France.

United Nations. (2007). World population ageing. New York: Author.
Veloz, M. C. T., Nascimento-Schulze, C. M., \& Camargo, B. V. (1999). Representações sociais do envelhecimento. Psicologia: Reflexão e Crítica, 12(2), 479-501.

Vergès, P. (1992). L’evocation de l'argent: une méthode pour la définition du noyau central de la représentation. Bulletin de Psychologie, 45(405), 203-209.

Wachelke, J. (2008). Relationship between evocation rank in social representations associative tasks and personal symbolic value. Revue Internationale de Psychologie Sociale, 21(3), 113-126.

Wachelke, J. F. R. (2009). Índice de centralidade de representações sociais a partir de evocações (INCEV): Estudo da representação social sobre envelhecimento. Psicologia: Reflexão e Crítica, 22(1), 102-110.

Wachelke, J. F. R., Camargo, B. V., Hazan, J. V., Soares, D. R., Oliveira, L. T. P., \& Reynaud, P. D. (2008). Princípios organizadores da representação social do envelhecimento: Dados coletados via internet. Estudos de Psicologia (Natal), 13(2), 107-116.

Wachelke, J. F. R., \& Lins, S. L. B. (2008). Changing masks: A masking effect on young people's social representation on aging? Current Research in Social Psychology, 13(19), 232-242.
Recebido: 17/05/2010 $1^{a}$ revisão: $27 / 09 / 2010$ $2^{a}$ revisão: 07/11/2010 Aceite final: 06/01/2011 